\title{
Fostering Innovative and Entrepreneurial Ability of College Students: A Prospective of Entrepreneurship
}

\author{
Xulei Chi \\ School of Finance \\ Qilu University of Technology \\ Jinan, P R.China \\ jn_cxl@163.com
}

\begin{abstract}
Inntoovation is the backbone of the rise of the state and the nation, while college students are the future of the state and the nation, therefore it is crucial to cultivate college students' innovative ability; on the other hand, start-ups have become an important channel for the graduates' employment because of the popularization of higher education in China, entrepreneurial ability must be fostered for college students. This paper finds that innovative ability and entrepreneurial ability are united in entrepreneurship, China's colleges and universities should reconstruct entrepreneurship teaching system, establish entrepreneurship extracurricular practice system in order to train students on innovative and entrepreneurial ability.
\end{abstract}

Keywords-entrepreneurship; ennovative ability; entrepreneurial ability; college students

\section{INTRODUCTION}

Throughout history and reality, innovation has been the most important power of economic development all the time. Once the nation or the state is good at innovation, it would develop rapidly and powerfully. The era of knowledge economy is coming, science and technology is changing rapidly, the comprehensive national strength is more related to high-tech competition, the innovation ability of the state or the nation are is more important than any time before. Because of this situation, the eighteen of the communist party of China has proposed the innovation-drive development strategy.

College students are the future of the state and the nation, Chinese college students shoulder the historical mission of the great rejuvenation of the Chinese nation, and the cultivation of the college students' innovation ability is the primary task of higher education.

At the same time, China's higher education has become a mass education, the employments of college graduates are becoming increasingly rigorous, college graduates can start their own businesses as a channel of employment, entrepreneurship education must be conducted for Chinese college students to cultivate their entrepreneurship and promote their entrepreneurial ability.

The cultivation of the college students' innovation ability and the implementation of entrepreneurship education can be unified in the cultivation of the entrepreneurship. Against this background, this paper discusses how to foster innovative ability and entrepreneurial ability of college students by the cultivation of the entrepreneurship

\section{INNOVATION ABILITY AND ENTREPRENEURIAL TRAITS ARE UNIFIED IN ENTREPRENEURSHIP}

\section{A. the connotation of entrepreneurship}

Entrepreneurship has wide range and rich content, scholars put forward different views, but they all focus on the entrepreneur's innovation spirit and adventure spirit. Frank Knight proposed the term "entrepreneurship" in earlier period, entrepreneurship is referred to the entrepreneur's ability; Schumpeter points out that entrepreneurship is composed of pioneering spirit, desire for success, adventurous spirit, smart and sharp characteristics, strong sense of professionalism. Management guru Peter Drunker equates entrepreneurship with social innovation spirit, and improves the spirit to the height of the social progress lever. Famous management expert Robbins, expressed entrepreneurship with more visualization, he thinks that entrepreneurship is "strong desire for achievement, high degree of confidence to grasp his own fate, and the moderate control of the risk". Weber thinks that entrepreneurship is a professional spirit, the pursuit of profit maximization of the spirit of capitalism, while professional dedication contains the sorrow breath awareness in entrepreneurs of the attention to enterprise survival, and experience failure without discouraging setbacks awareness, and so on, North stresses entrepreneurship is a spirit of cooperation, With the complicated modern social division of labor and enterprise competition, it requires entrepreneurs continuously carry forward the spirit of cooperation, trust each other and get through tough time together. OECD defines entrepreneurship as "the courage to take risks and innovation, while innovation means to create new products and services, take risks involves to identify new market opportunities".

\section{B. innovation ability needs entrepreneurship}

Innovation ability refers to the knowledge, ability and intelligence of main body of innovation, innovation ability requires great ideal, strong dedication to work, enterprising spirit and indomitable will, which is the spirit of innovation. Innovation ability and innovative spirit interact complementarily on objects to conduct the conversion process of information, material and energy, resulting in a new knowledge, the new theory, new method and new achievements of social value.

According to the definition of scholars for entrepreneurship, entrepreneurship should include at least the innovative spirit, dedication spirit, cooperation spirit, adventure spirit and 
integrity spirit, etc. the innovation spirit is the kernel of entrepreneurship, and Chinese economist Fan Gang thinks that entrepreneurship is a kind of innovation spirit, both adventure spirit and personal reason.

Thus, we can get such logic, the cultivation of the college students' innovation ability needs to the cultivation of innovation spirit and innovation spirit is the core of the entrepreneurial spirit, entrepreneurial spirit is a kind of more comprehensive quality than the spirit of innovation, the cultivation of college students' entrepreneurship is a higher level of demand.

\section{Entrepreneurial traits and entrepreneurship are internally consistent}

Successful entrepreneurs need entrepreneurial ability which mainly includes the knowledge, skills and qualities. Knowledge includes business opportunities, market, customers, competitors, products, management and resources, etc; Skills includes many technologies such as engineering technology, computing technology, and many management abilities such as marketing, financial management, organization, planning, and leadership; Qualities is mainly full of dedication and enterprising spirit, which can be embodied as exuberant energy, desire, creative thinking, courage to bear risks, the tenacious perseverance, team spirit, excellent organization leadership and a high degree of social responsibility.

Research on the entrepreneurial ability which successful entrepreneurs need shows that the entrepreneurs' characteristics are consistent with the essence of entrepreneurship. Namely, both entrepreneurial traits and entrepreneurial spirit, innovative spirit, professionalism, dedication, and a high degree of social responsibility are the most basic quality they should reflect.

\section{REFACTORING TRAINING TEACHING SYSTEM TO CULTIVATE ENTREPRENEURSHIP}

\section{A. Change the traditional education and teaching ideas}

Traditional education concept emphasizes teachers, textbooks and classroom-centered Knowledge Impartation, and focuses on standardization and the unity of the education, while ignoring the differences between educators and the differences between individuals, trying to make education to be standard, obedient, exam-oriented education and make the students into the knowledge, technical elite, which has seriously restricted the cultivation of college students' innovation ability and development.

In order to cultivate college students' entrepreneurship, we must change the traditional education and teaching idea, establish and perfect the teaching system with students as the center, with teachers as the main body, with curriculum as the carrier of teaching system, and the education goal should be to cultivate high quality talents with creative ability, innovative spirit and noble character to meet socio-economic needs. In the classroom, teaching orientation should be transferred knowledge master to harmonious development of knowledge, ability and personality; the teaching method should be transferred from force-feeding teaching to research teaching, practical teaching; the teaching quality evaluation should be transferred from attaching great importance to the evaluation of the "teaching" to paying attention to the evaluation of "learning".

\section{B. Reconstruct teaching course system}

Teaching course is the main channel to complete the task of education according to the teaching goal, and in order to cultivate college students' comprehensive ability, especially innovative and entrepreneurial ability, we should apply the connotation and the essence of entrepreneurship to transform the original vertical branch curriculum, desalt disciplinary boundaries, pay attention to the integration and penetration between disciplines and specialties, update the teaching material so that a three-dimensional teaching system interchange can be established. At the same time, we may open entrepreneurship education courses to breakthrough current cultivating mode, the entrepreneurship curriculum should be set up from the entrepreneurs' quality, company establishment, operation and management, corporate venture consciousness and so on, thus a teaching system which innovation as it's core can be formed, under the teaching system, the student can choose their suitable courses to enhance the ability of students to acquire knowledge, analyze problems and the ability to capture opportunities.

\section{Reform teaching methods}

Now institutions of higher learning in developed countries are focusing on using the discovery method and discussion method in teaching, they attach great importance to improve college students' abilities of independent research, abilities to be conscious and abilities to create, actively improve learning methods and teaching methods to give students the whole autonomous learning space. College students should be encouraged to suit their own learning progress in learning career and learning manner, creating opportunities for students to try and to form independent discoveries and independent innovation ability. The original "cramming education" in teaching pattern should be changed, innovating teaching methods, the flexible teaching methods combined with practice should be adopted, which changes the one-way teaching to the two-way teaching; Teachers must implement the difference principle to teach students according to their aptitude, students must learn based on material selection, creating a learning way which suits to the characteristics of the students. It should be insisted on the principle that combining teachers' domination with students' subjectivity, in the teaching process students should be given play to their initiative and enthusiasm under the guidance of teachers, college students should select materials and learning style, which may reflect individual characteristic and make it relatively independently to explore and study.

\section{Reform the way of course testing}

Traditional college course examination method does not adapt with the cultivation of innovative ability and entrepreneurial ability, because knowledge oriented exam is bad for students to improve innovative ability, the misunderstanding of the examination function is unfavorable to students' active learning, the accident of grades evolution is not conducive to the formation of good style of study. Therefore, we should reform course testing method; testing methods should be flexible to combine the process of examination with 
the assessment of the end examination, because teaching is a dynamic and continuous process, examination, a means of the evaluation of teaching quality, should aim at objective evaluation, the evaluation activity should be not only different in different class, but also throughout the whole teaching process.

Examination and appraisal of the course can be taken with many forms from several aspects and stages to examine student's learning process that give full play to the advantages of all kinds of examination forms, enhancing rational and scientific assessment and making the test to be optimized, so as to motivate students to strengthen and improve the level of knowledge and skills, students will study with the passive state to form autonomous learning ability, thinking ability, imagination ability, expression ability, practice ability and innovation ability.

\section{ESTABLISH EXTRACURRICULAR PRACTICE SYSTEM TO TRAIN ENTREPRENEURSHIP}

Colleges and universities are not only necessary to bring the goal of cultivating college students' entrepreneurship into existing career planning and entrepreneurship education curriculum teaching system, but also need to formulate and implement the practical training support programs to promote college students' entrepreneurship training.

\section{A. promote the campus culture which have entrepreneurship}

China's current cultural environment determines that concepts of education should be updated in order to implement entrepreneurship education. First of all, in the campus culture, we'd better guide college students to integrate traditional culture, screen traditional culture, and promote traditional culture innovation, overcome its conservative and negative side, and integrate it with entrepreneurship, and further stimulate, sublimate entrepreneurship with traditional culture. Secondly, we should shape the competitive atmosphere on campus, and break the thinking mode of rut, not seek fame, advocating the hero concept of bold breakthrough pioneer. In addition, we have to overcome the thought of "ranking of college students", so that they recognize that the measure of a person value is the wealth they create and the contribution they make to society in the era of knowledge economy.

\section{B. Organize business club activities carefully}

The essential feature of entrepreneurship is innovation and responsibility, which of the external performance is to start an undertaking. In the market economy, both "innovation" and "responsibility" is essential for survival and development for the individual or organization. Entrepreneurial club activities are very important to cultivate college students' "innovation" and "responsibility" consciousness. Entrepreneurial club activities include social investigation, volunteer service, workstudy programs, campus scientific research subject, extracurricular science and technology competition, innovative start-ups, cold and summer social practice, etc.

College students' community management may center to "service, coordination and guidance" for the purpose of the work, we must change the traditional "book type", "force type" for teaching management mechanism to "mutual promotion of teaching and learning" so as to penetrate entrepreneurship to the community practice. It is the embodiment of "innovation" and "responsibility" to create necessary environment and conditions for entrepreneurial aspirations and potential college students.

In entrepreneurial club activities management, managers need to urge the community on the one hand to work in strict accordance with the articles of association and internal working system, regulating the behavior of its members, guaranteeing the society steady carried out. On the other hand, they need to actively encourage students to challenge themselves, to cultivate students' innovation, competition, teamwork, responsibility, cultivate their consciousness of audacity, selfconfidence, fortitude, optimism, open-minded and other personality traits, cultivate their spirit of adventure and the ability to resist interference.

\section{C. organize extracurricular science and technology competition activities carefully}

The national "challenge cup" business plan competition is a good way to cultivate college students' pioneering consciousness, entrepreneurial spirit and entrepreneurial ability. Universities and colleges should take "challenge cup" and other entrepreneurial competition for leading college students' extracurricular science and technology competition, promote students' research and development, Further, Universities and colleges should input or absorb capital to develop and construct business incubator and venture demonstration, and construct students' planning and advisory body; Finally, the achievements with good application value should be lead into business incubator, and good ideas should be funded, and make college students "learning to do, do and learning ".Then we can tie the students' entrepreneurial activities with subject innovation advantage, realize production-teaching-research combination, establish a fund and transformation system from scientific and technological innovation to the entrepreneurial practice.

\section{Establish and make full use of the entrepreneurial practice bases}

The spirit of innovation is the essence of entrepreneurship, and action consciousness and behavior ability is exact embodiment of the spirit. Entrepreneurship practice bases is one of the most important platform to cultivate talents with innovative spirit and practice ability, so universities and colleges should establish various business practice bases according to the characteristics of major, uniting industrial and commercial enterprises, professional consulting firms, financial institutions. Meanwhile, business practice bases should be made good use, letting the students in a variety of possible time to trainee or practice in these bases, exercising their practice ability and entrepreneurial ability, enhancing their entrepreneurial experience, and experiencing entrepreneurship from practice.

\section{CONCLUSION}

With the advent of the era of knowledge economy, innovation ability has become a key to the rise and fall of the state and the nation, to train the innovative ability of college students has become a heavy bear responsibility for university 
and colleges; On the other hand, the popularization of higher education in China, the employment pressure of college graduates becomes heavier, self-employment becomes an important channel .

The cultivation of innovation ability and entrepreneurial ability can be unified in the cultivation of entrepreneurship. In this context, this paper discussed how to cultivate entrepreneurship so as to cultivate students' innovation ability and entrepreneurial ability from the aspects of teaching system and extracurricular practice system. But it is a complex system engineering to cultivate college students' innovation ability and entrepreneurial ability based on entrepreneurship, which needs efforts of the government, colleges, society and the families.

\section{REFERENCES}

[1] Gong Yizu. On university personnel training modes. Nanjing: Jiangsu Education Press, 1999, pp123-128.

[2] Zhang Yuli. Entrepreneurship and entrepreneurial spirit: the thinking mode and conduct of managers. Nankai Journal (philosophy and social sciences edition), No. 1, 2004, pp12-15.

[3] Liu Xinmin, Guo Hongbo. Analysis on Contemporary College students' entrepreneurship education. Journal of Shandong Youth Administrative Cadres College, No. 4, 2007, pp.61-63.

[4] Li Zhi, Cao Yuequn. Analysis of contents in research literature of entrepreneur spirit. Journal of Chongqing Technology and Busisness University (social science edition), vol. 20, 2003, pp.79-81.

[5] Zhang Yuli, Yang Jun. Foreign Entrepreneurship Education and Its Implications. Journal of China University of Geosciences (social sciences edition), vol. 4, 2004, pp.22-27. 